\section{CrossMark} $\leftarrow$ click for updates

Cite this: Mol. BioSyst., 2016, 12,67

Received 14th October 2015 Accepted 29th October 2015

DOI: $10.1039 / \mathrm{c} 5 \mathrm{mb} 00692 \mathrm{a}$

www.rsc.org/molecularbiosystems

\title{
New oligonucleotide derivatives as unreactive substrate analogues and potential inhibitors of human apurinic/apyrimidinic endonuclease APE1
}

\author{
Nikita A. Kuznetsov, ${ }^{a b}$ Maxim S. Kupryushkin, ${ }^{a}$ Tatyana V. Abramova, \\ Alexandra A. Kuznetsova, ${ }^{a}$ Anastasia D. Miroshnikova, ${ }^{a}$ Dmitry A. Stetsenko, ${ }^{a b}$ \\ Dmitrii V. Pyshnyi ${ }^{\mathrm{ab}}$ and Olga S. Fedorova*ab
}

\begin{abstract}
Human apurinic/apyrimidinic endonuclease APE1 is one of the key enzymes of the base excision DNA repair system. The main biological function of APE1 is the hydrolysis of the phosphodiester bond on the $5^{\prime}$-side of an apurinic/apyrimidinic site (AP-site) to give the $5^{\prime}$-phosphate and $3^{\prime}$-hydroxyl group. It has long been known that AP-sites have mutagenic and cytotoxic effects and their accumulation in DNA is a potential hazard to the cell lifecycle. The structural and biochemical studies of APE1 are complicated by its high catalytic activity towards the AP-site and its cyclic or acyclic analogues. This work has focussed on the design, synthesis and analysis of oligonucleotide derivatives as potentially unreactive APE1 substrates. We have shown that the replacement of oxygen atoms in the phosphate group on the $5^{\prime}$-side from the AP-site analogue tetrahydrofuran (F) considerably decreases the rate of enzymatic hydrolysis of modified oligonucleotides. We have calculated that a N3'-P5' phosphoramidate linkage is hydrolysed about 30 times slower than the native phosphodiester bond while phosphorothioate or primary phosphoramidate linkages are cleaved more than three orders of magnitude slower. The value of $I C_{50}$ of the oligonucleotide duplex containing a primary phosphoramidate linkage is $2.5 \times 10^{-7} \mathrm{M}$, which is in accordance with the APE1 association constant of DNA duplexes containing AP-sites. Thus, it is demonstrated that oligonucleotide duplexes with chemical modifications could be used as unreactive substrates and potential competitive inhibitors of APE1.
\end{abstract}

\section{Introduction}

Keeping DNA intact is the key to safeguarding genetic information and smooth running of all vital processes in the cell. In a mammalian genome of billions of nucleotides some 100000 lesions per day may occur. ${ }^{1-4}$ Genotoxicity may result from a number of endogenous factors such as side effects of normal cell metabolites, and exogenous factors such as UV irradiation, ionising radiation and a variety of mutagenic chemical compounds. ${ }^{5,6}$

It is thought that a majority of nucleobase lesions are removed via the base excision repair (BER) pathway. ${ }^{7-9}$ This process is initiated by DNA glycosylases, which find lesions amongst all the undamaged bases and catalyse break-up of $N$-glycosidic bonds. ${ }^{10,11}$ After the action of DNA glycosylases the resulting apurinic/apyrimidinic site (AP-site) is targeted by apurinic/apyrimidinic endonuclease

\footnotetext{
${ }^{a}$ Institute of Chemical Biology and Fundamental Medicine, Siberian Branch of the Russian Academy of Sciences, Novosibirsk 630090, Russia.

E-mail: fedorova@niboch.nsc.ru

${ }^{b}$ Department of Natural Sciences, Novosibirsk State University, Novosibirsk 630090, Russia
}

that cleaves the $5^{\prime}$-phosphate bond. The nick contains a hydroxyl group on the $3^{\prime}$-end and a 2 -deoxyribonucleoside- 5 '-phosphate on the $5^{\prime}$-end. Later stages of repair are performed by DNA polymerases and DNA ligases, which restore the initial DNA sequence. ${ }^{12,13}$

Disruptions in the work of DNA repair enzymes cause severe consequences such as premature aging, cancer and other diseases. ${ }^{14-17}$ It was shown that cells or animals in which some DNA glycosylase genes are knocked out become more sensitive to DNA-damaging factors. ${ }^{18-21}$ At the same time exclusion of the second player of the BER pathway AP-endonuclease results in cell death, which reveals a critical role APE1 plays in the restoration of the native DNA structure. ${ }^{22}$

Thus, the level of enzymatic activity of human AP-endonuclease APE1 has a considerable influence on the process of the removal of DNA lesions. APE1 is an extremely active enzyme, ${ }^{23,24}$ which is able to process many synthetic analogues of the AP-site such as tetrahydrofuran (F-site) or $\alpha, \omega$-alkanediols. ${ }^{24-26}$

Analysis of crystal structures of free APE1 ${ }^{27-29}$ and its complexes with $\mathrm{DNA}^{30-32}$ shows that currently there is still some uncertainty in our understanding of the multiple catalytic functions of the enzyme. Moreover, the stoichiometry of the divalent 
cations and their catalytic functions are still not clear. ${ }^{27-29,33,34}$ Therefore, the important aspects of the APE1-mediated catalytic mechanism remain unresolved due to the lack of convenient unreactive analogues of APE1 substrates.

The objective of this study was to prepare modified oligonucleotide derivatives and ascertain their utility in vitro as unreactive substrate analogues of human apurinic/apyrimidinic endonuclease APE1. Some of these derivatives may also have potential as inhibitors of APE1 in vivo. APE1 inhibition is expected to enhance genotoxicity of DNA lesions and accelerate cell death, which is the goal of radiation therapy and chemotherapy of cancer. On-going development of effective systems for cell delivery of DNA and RNA derivatives ${ }^{35}$ allows us to believe that those oligonucleotide inhibitors of APE1 may find their use in near future as effective and stable in vivo therapeutics.

\section{Results and discussion}

Rational design of oligonucleotide derivatives as potential APE1 inhibitors

Information on the mechanism of the APE1-catalysed reac$\operatorname{tion}^{25,28,30,36,37}$ prompted us to hypothesise that if we substitute the $\mathrm{NH}$ group for the $3^{\prime}$-bridging oxygen atom in the phosphate group of the nucleotide on the $5^{\prime}$-side from the AP-site to form an $\mathrm{N}^{\prime}-\mathrm{P}^{\prime}$ phosphoramidate, or sulphur $\mathrm{S}$, an amino group $\mathrm{NH}_{2}$ or a 1,1,3,3-tetramethylguanidine (Tmg) group for any of the non-bridging oxygen atoms in the same phosphate group (Fig. 1), we disrupt its interactions with $\mathrm{Mg}^{2+}$ cations and amino acid residues in the active centre of the enzyme, which will likely decrease the rate of the catalytic reaction. Thus, in this work we set out to synthesise oligonucleotides incorporating those substitutions (Fig. 2 and Table 1). As APE1 exhibits also $3^{\prime}-5^{\prime}$-exonuclease activity albeit less pronounced compared to its endonuclease activity, the $3^{\prime}$-terminal internucleotide phosphate group was chemically modified by the replacement of its oxygen atom by either a sulphur or a Tmg group to make the phosphate resistant to the exonuclease activity of the enzyme (Fig. 2 and Table 1).

Instead of the natural AP-site, the oligonucleotides incorporated its chemically stable analogue $(2 R, 3 S)$-2-(hydroxymethyl)-3-hydroxytetrahydrofuran (F-site). It is known that such a substitution scarcely affects the activity of APE1. ${ }^{24-26,38,39}$

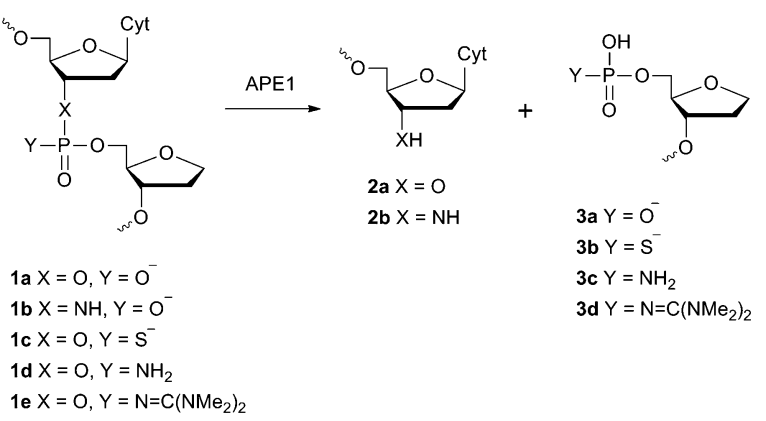

Fig. 1 Structure of the F-site and chemical modifications of the phosphate group on its $5^{\prime}$-side that are resistant to APE1 hydrolysis.

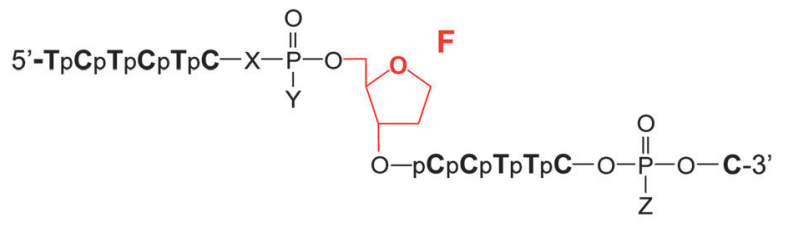

5'-GpGpApApGpGpGpGpApGpApG-O-

Fig. 2 Oligonucleotide structures. Chemical modifications of phosphate groups are listed in Table 1.

Table 1 Chemical modifications of phosphate groups and abbreviations of oligonucleotides

\begin{tabular}{ll}
\hline Abbreviation & Chemical modification of the phosphate group \\
\hline $\mathrm{F}^{\mathrm{O}}$ & $\mathrm{X}=\mathrm{O}, \mathrm{Y}=\mathrm{O}^{-}, \mathrm{Z}=\mathrm{O}^{-}$ \\
$\mathrm{F}^{3 / \mathrm{N}}$ & $\mathrm{X}=\mathrm{NH}, \mathrm{Y}=\mathrm{O}^{-}, \mathrm{Z}=\mathrm{O}^{-}$ \\
$\mathrm{F}^{\mathrm{S}}$ & $\mathrm{X}=\mathrm{O}, \mathrm{Y}=\mathrm{S}^{-}, \mathrm{Z}=\mathrm{O}^{-}$ \\
$\mathrm{F}^{\mathrm{SS}}$ & $\mathrm{X}=\mathrm{O}, \mathrm{Y}=\mathrm{S}^{-}, \mathrm{Z}=\mathrm{S}^{-}$ \\
$\mathrm{F}^{\mathrm{N}}$ & $\mathrm{X}=\mathrm{O}, \mathrm{Y}=\mathrm{NH}_{2}, \mathrm{Z}=\mathrm{O}^{-}$ \\
$\mathrm{F}^{\mathrm{NB}}$ & $\mathrm{X}=\mathrm{O}, \mathrm{Y}=\mathrm{NH}_{2}, \mathrm{Z}=\mathrm{Tmg}^{a}$ \\
$\mathrm{~F}^{\mathrm{BB}}$ & $\mathrm{X}=\mathrm{O}, \mathrm{Y}=\mathrm{Tmg}_{\mathrm{Z}} \mathrm{Z}=\mathrm{Tmg}^{\mathrm{O}}$ \\
$\mathrm{G}^{\mathrm{O}}$ & $\mathrm{Z}=\mathrm{O}^{-}$ \\
$\mathrm{G}^{\mathrm{S}}$ & $\mathrm{Z}=\mathrm{S}^{-}$ \\
$\mathrm{G}^{\mathrm{B}}$ & $\mathrm{Z}=\mathrm{Tmg}$ \\
${ }^{a} \mathrm{Tmg}-1,1,3,3$-tetramethylguanidine group &
\end{tabular}

\section{Chemical synthesis of oligonucleotides with modified phosphate groups}

An oligonucleotide with a N3'-P5' phosphoramidate group was prepared using a dimer phosphoramidite I according to the approach described in ref. 40. Chemical synthesis of the dimer phosphoramidite I was accomplished as shown in Fig. 3. A known $5^{\prime}$-protected $(2 R, 3 S)$-2-(hydroxymethyl)-3-hydroxy-tetrahydrofuran $\mathbf{I I}^{41}$ was converted to $3^{\prime}$-protected compound III. After its $5^{\prime}$-phosphitylation and hydrolysis of the transient phosphoramidite $H$-phosphonate diester IV was obtained that was in turn reacted with protected $3^{\prime}$-deoxy-3'-aminocytidine $\mathbf{V} .{ }^{40}$ After the selective removal of the levulinyl group and $3^{\prime}$-phosphitylation the desired dimer phosphoramidite I was obtained that was subsequently used in the synthesis of an oligonucleotide containing the AP-site mimic $\mathrm{F}$ and the $\mathrm{N} 3^{\prime}-\mathrm{P}^{\prime}$ phosphoramidate internucleotide linkage on the $5^{\prime}$-side of the F-site. To confirm that the $\mathrm{P}-\mathrm{N}$ bond would be stable to the conditions of oligonucleotide synthesis, the protected dimer VI was unblocked by applying standard procedures of oligonucleotide deprotection, i.e. conc. aq. ammonia, $3 \mathrm{~h}$ at $55{ }^{\circ} \mathrm{C}$, then $80 \%$ acetic acid, $30 \mathrm{~min}$. The product was analysed by mass-spectroscopy. Its ESI-MS spectrum contained the only peak with $\mathrm{m} / \mathrm{z} 405.10$ that corresponded to the molecular ion $[\mathrm{M}-\mathrm{H}]^{-}$of the fully unprotected dinucleotide VI.

Dimer phosphoramidite I was used in automated oligonucleotide synthesis together with regular nucleoside phosphoramidites to obtain the model oligonucleotides (Fig. 2 and Table 1). 

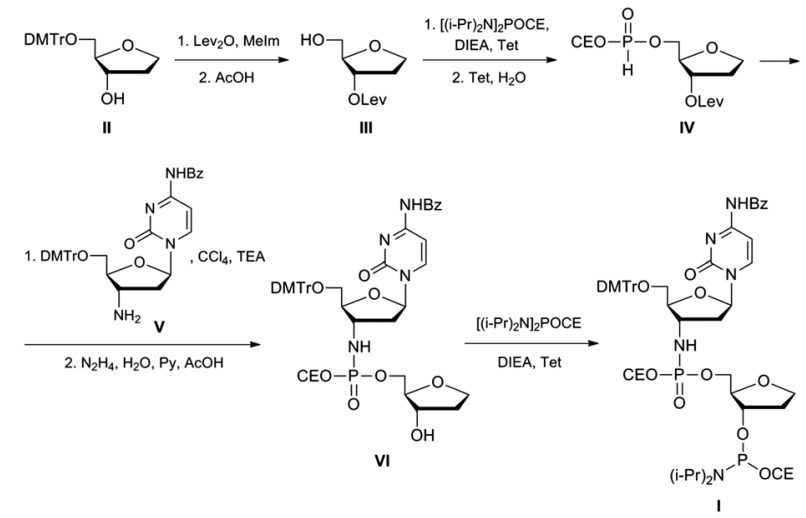

Fig. 3 Synthesis of a dimer phosphoramidite I.

Analysis of the rate of hydrolysis by APE1 of oligonucleotides with modified phosphate groups incorporated into DNA substrate duplexes

The efficiency of enzymatic hydrolysis by APE1 of doublestranded (ds) DNA substrates containing oligonucleotides with modified phosphate groups was ascertained by the separation of hydrolysis products by PAGE. Observed rate constants of chain scission for duplexes with substitutions only in the phosphate group on the $5^{\prime}$-side of the F-site were found to decrease in the order of $\mathrm{F}^{\mathrm{O}} / \mathrm{G}^{\mathrm{O}}>\mathrm{F}^{3 / \mathrm{N}} / \mathrm{G}^{\mathrm{O}} \gg \mathrm{F}^{\mathrm{N}} / \mathrm{G}^{\mathrm{O}}>\mathrm{F}^{\mathrm{S}} / \mathrm{G}^{\mathrm{O}}$ (Fig. 4 and Table 2). Interestingly, the $\mathrm{N} 3^{\prime}-\mathrm{P} 5^{\prime}$ phosphoramidate linkage $1 \mathrm{~b}$ in the DNA duplex $\mathrm{F}^{3 / \mathrm{N}} / \mathrm{G}^{\mathrm{O}}$ is hydrolysed only about 30 times slower than the native phosphodiester group 1a in the unmodified DNA duplex $\mathrm{F}^{\mathrm{O}} / \mathrm{G}^{\mathrm{O}}$. At the same time, oligonucleotides with phosphorothioate group 1c or primary phosphoramidate group 1d are hydrolysed more than three orders of magnitude slower than the unmodified duplex. Therefore, oligonucleotides containing those modifications could be potentially promising candidates for binding to and inhibiting the activity of APE1.

As could be seen from the above data, the endonuclease activity of APE1 is considerably retarded for DNA duplexes containing phosphate modifications on the $5^{\prime}$-side of the F-site.

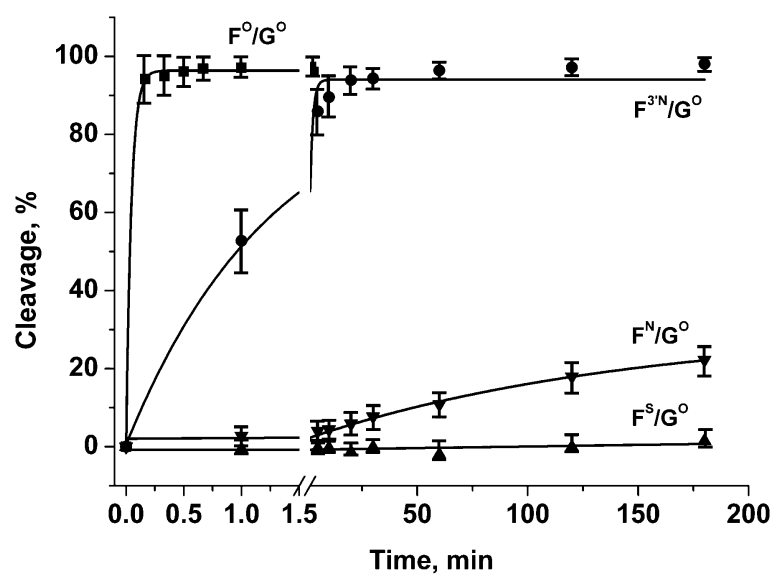

Fig. 4 Endonuclease activity of APE1 towards DNA duplexes with modified phosphate groups on the $5^{\prime}$-side of the F-site. $[$ APE1 $]=[\mathrm{dsDNA}]=1.0 \mu \mathrm{M}$.
Table 2 The observed rate constants of DNA substrate cleavage by APE1 and dissociation constants of APE1/DNA substrate complexes

\begin{tabular}{lll}
\hline DNA substrate & $\begin{array}{l}\text { Observed rate } \\
\text { constant } k_{\text {obs }}, \mathrm{min}^{-1}\end{array}$ & $\begin{array}{l}\text { Dissociation } \\
\text { constant } K_{\mathrm{d}}, \mathrm{M}^{a}\end{array}$ \\
\hline $\mathrm{F}^{\mathrm{O}} / \mathrm{G}^{\mathrm{O}}$ & $22.4 \pm 2.4$ & $\mathrm{ND}$ \\
$\mathrm{F}^{3 / \mathrm{N}} / \mathrm{G}^{\mathrm{O}}$ & $0.8 \pm 0.1$ & $(0.5 \pm 0.4) \times 10^{-7}$ \\
$\mathrm{~F}^{\mathrm{N}} / \mathrm{G}^{\mathrm{O}}$ & $(6.8 \pm 2.4) \times 10^{-3}$ & $(1.5 \pm 0.5) \times 10^{-7}$ \\
$\mathrm{~F}^{\mathrm{S}} / \mathrm{G}^{\mathrm{O}}$ & $<1.0 \times 10^{-4}$ & $(1.1 \pm 0.1) \times 10^{-7}$ \\
$\mathrm{~F}^{\mathrm{NB}} / \mathrm{G}^{\mathrm{B}}$ & $(1.9 \pm 0.4) \times 10^{-2}$ & $\mathrm{ND}$ \\
$\mathrm{F}^{\mathrm{BB}} / \mathrm{G}^{\mathrm{B}}$ & $<1.0 \times 10^{-4}$ & $\mathrm{ND}$ \\
${ }^{a}$ Obtained by fluorescence titration. &
\end{tabular}

However, analysis of the products of chain scission of those duplexes has revealed that some $3^{\prime}-5^{\prime}$-exonuclease reaction that removes the $3^{\prime}$-terminal nucleotide has also occurred. To suppress the removal of the $3^{\prime}$-terminal nucleotide from the model oligonucleotides, their $3^{\prime}$-terminal internucleotide phosphate group was modified (Fig. 2 and Table 1). The tetramethyl phosphoryl guanidine group (Tmg) was employed as a nuclease-resistant phosphate group isostere. ${ }^{42}$ It was observed that such a modification blocks $3^{\prime}-5^{\prime}$-exonuclease activity of APE1 for more than $12 \mathrm{~h}$. The group was also tested as a protecting group for the phosphate group on the $5^{\prime}$-side of the F-site 1e (Fig. 1). The data obtained by PAGE analysis of reaction products have shown that the duplex containing the dinucleotide 1e was resistant to the endonuclease action of APE1 for at least $3 \mathrm{~h}$ (Fig. 5 and Table 2).

Comparison of cleavage efficacy (Fig. 6) of the modified oligonucleotide derivatives has shown that the modifications reduce enzymatic activity of APE1 in the order $\mathrm{F}^{\mathrm{O}} / \mathrm{G}^{\mathrm{O}} \gg \mathrm{F}^{3 / \mathrm{N}} / \mathrm{G}^{\mathrm{O}} \gg$ $\mathrm{F}^{\mathrm{NB}} / \mathrm{G}^{\mathrm{B}}>\mathrm{F}^{\mathrm{N}} / \mathrm{G}^{\mathrm{O}}>\mathrm{F}^{\mathrm{S}} / \mathrm{G}^{\mathrm{O}} \approx \mathrm{F}^{\mathrm{BB}} / \mathrm{G}^{\mathrm{B}}$.

\section{Binding of DNA duplexes to APE1}

To ascertain the efficacy of APE1 binding to modified DNA duplexes, the kinetics of enzyme-substrate complex formation was studied by the "stopped-flow" method. The kinetic curve of the APE1 reaction with duplex $\mathrm{F}^{\mathrm{O}} / \mathrm{G}^{\mathrm{O}}$ goes through characteristic phases (Fig. 7). The data for the APE1 interaction with

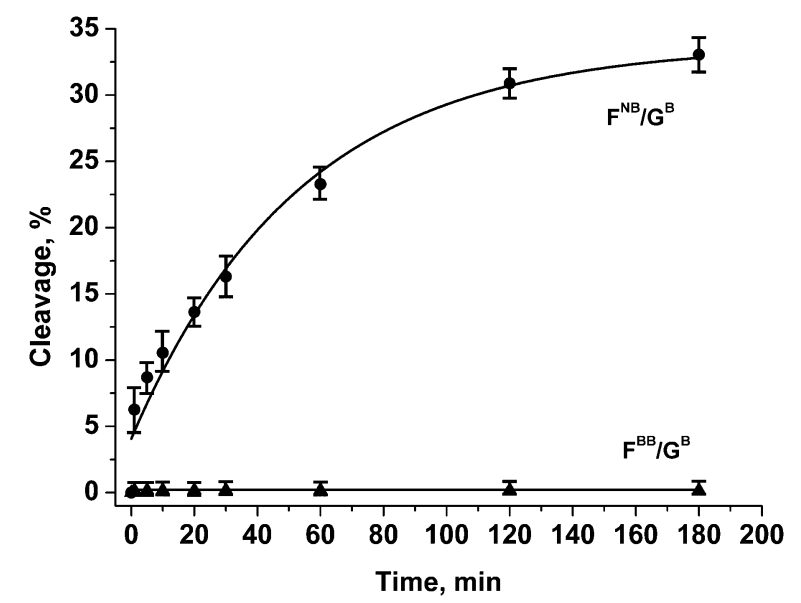

Fig. 5 Endonuclease activity of APE1 towards DNA duplexes with modified phosphate groups on the $5^{\prime}$-side of the F-site and in the $3^{\prime}$-internucleotide position. $[$ APE1 $]=[\mathrm{dsDNA}]=1.0 \mu \mathrm{M}$. 


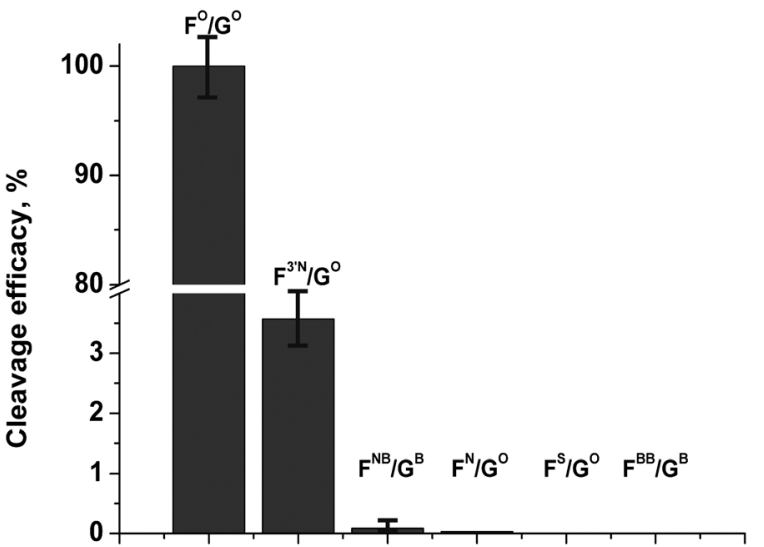

Fig. 6 Comparison of cleavage efficacy of modified oligonucleotide derivatives. $[$ APE1 $]=[$ dsDNA $]=1.0 \mu \mathrm{M}$.

duplexes incorporating the F-site that were published in ref. 38 and 39 prompted us to conclude that the initial (up until 0.1 seconds) decrease in fluorescence intensity could be attributed to the process of the formation of an enzyme-substrate complex that is responsible for the catalytic hydrolysis of the internucleotide phosphodiester bond. After that initial period within 0.1-10 seconds the complex dissociates with the concomitant release of the products of the reaction, which results in the increase in fluorescence intensity. As it is shown in Fig. 7, the interaction of APE1 with duplexes $\mathrm{F}^{\mathrm{N}} / \mathrm{G}^{\mathrm{O}}$ and $\mathrm{F}^{\mathrm{NB}} / \mathrm{G}^{\mathrm{B}}$ until $0.1 \mathrm{~s}$ was accompanied by only the decrease in fluorescence intensity that correlates with the formation of an enzyme-substrate complex. At the same time the interaction of APE1 with duplex $\mathrm{F}^{\mathrm{BB}} / \mathrm{G}^{\mathrm{B}}$ did not result in any change in fluorescence intensity. This result may suggest that the presence of a bulky Tmg group on the $5^{\prime}$-side of the F-site has prevented the formation of an enzyme-substrate complex.

To estimate the dissociation constant of the enzyme/inhibitor complex, APE1 was titrated with $\mathrm{F}^{3 / \mathrm{N}} / \mathrm{G}^{\mathrm{O}}, \mathrm{F}^{\mathrm{N}} / \mathrm{G}^{\mathrm{O}}$ and $\mathrm{F}^{\mathrm{S}} / \mathrm{G}^{\mathrm{O}}$ duplexes. The change in APE1 protein fluorescence is shown in Fig. 8.

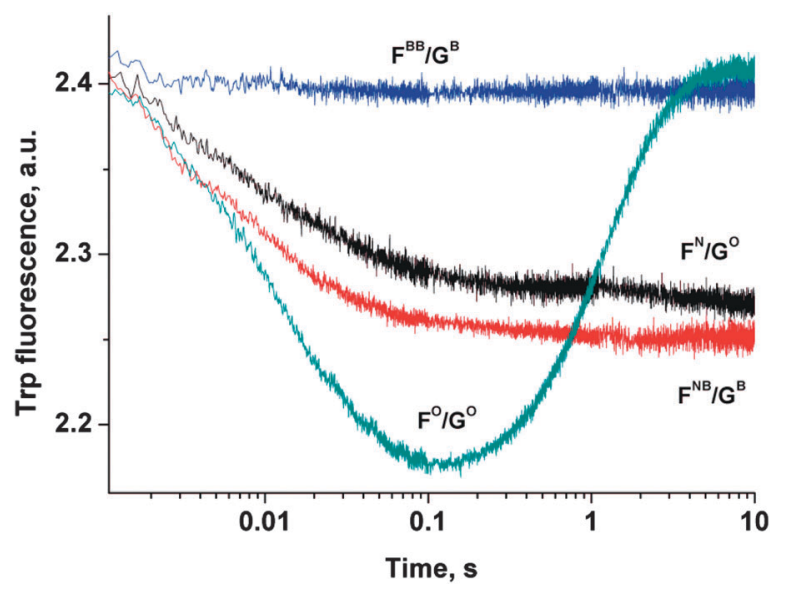

Fig. 7 Kinetic curves of Trp fluorescence emission change during the APE1 interaction with modified DNA duplexes. $[$ APE1 $]=[\mathrm{dsDNA}]=1.0 \mu \mathrm{M}$.

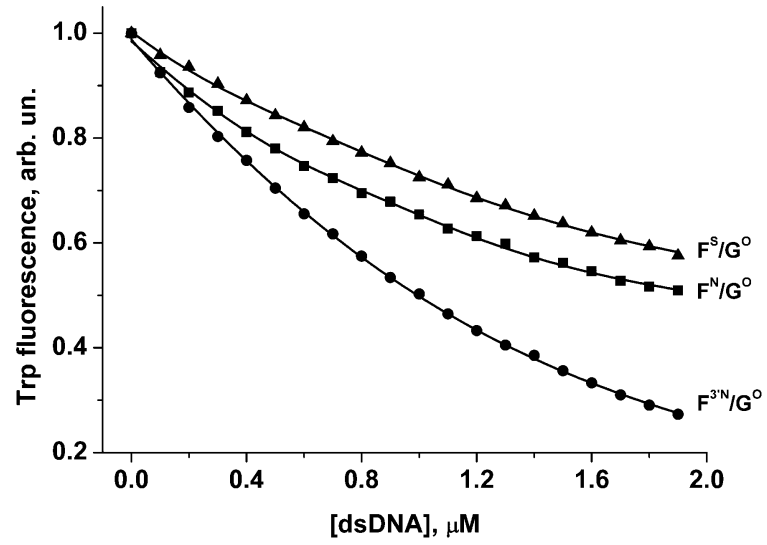

Fig. 8 Change in APE1 fluorescence during titration with $\mathrm{F}^{3 / N} / \mathrm{G}^{\circ}, \mathrm{F}^{\mathrm{N}} / \mathrm{G}^{\mathrm{O}}$ and $\mathrm{F}^{\mathrm{S}} / \mathrm{G}^{\mathrm{O}}$ duplexes. [APE1] $=1.0 \mu \mathrm{M}$. Triangle, $\mathrm{F}^{\mathrm{S}} / \mathrm{G}^{\mathrm{O}}$ duplex; square, $\mathrm{F}^{\mathrm{N}} / \mathrm{G}^{\mathrm{O}}$ duplex; circle, $\mathrm{F}^{3 / \mathrm{N}} / \mathrm{G}^{\mathrm{O}}$ duplex.

Quenching of the Trp fluorescence was registered for all these DNA duplexes. The calculated dissociation constants $K_{\mathrm{d}}$ are listed in Table 2. It is worthy of note that values of $K_{\mathrm{d}}$ for $\mathrm{F}^{\mathrm{N}} / \mathrm{G}^{\mathrm{O}}$ and $\mathrm{F}^{\mathrm{S}} / \mathrm{G}^{\mathrm{O}}$ duplexes are approximately the same considering the standard deviation interval. It is also noteworthy that the $\mathrm{F}^{3 / \mathrm{N}} / \mathrm{G}^{\mathrm{O}}$ duplex is partially cleaved during the titration time. Probably, due to this fact the value of $K_{\mathrm{d}}$ for the $\mathrm{F}^{3 / \mathrm{N}} / \mathrm{G}^{\mathrm{O}}$ duplex is $2-3$ times lower in comparison with $\mathrm{F}^{\mathrm{S}} / \mathrm{G}^{\mathrm{O}}$ or $\mathrm{F}^{\mathrm{N}} / \mathrm{G}^{\mathrm{O}}$ duplexes, respectively.

\section{Assessment of inhibition efficacy}

For one of the promising inhibitors of APE1, duplex $\mathrm{F}^{\mathrm{N}} / \mathrm{G}^{\mathrm{O}}$, we have assessed the inhibition effect for the reaction of hydrolysis of a DNA substrate $\mathrm{F}^{\mathrm{O}} / \mathrm{G}^{\mathrm{O}}$. For this, duplex $\mathrm{F}^{\mathrm{N}} / \mathrm{G}^{\mathrm{O}}$ in various concentrations was added to the mixture of APE1 and $\mathrm{F}^{\mathrm{O}} / \mathrm{G}^{\mathrm{O}}$. As it could be seen in Fig. 9A, the rate of hydrolysis of a DNA substrate $\mathrm{F}^{\mathrm{O}} / \mathrm{G}^{\mathrm{O}}$ was considerably decreased in the presence of $\mathrm{F}^{\mathrm{N}} / \mathrm{G}^{\mathrm{O}}$. The dependence of the observed reaction rate on the concentration of the inhibitor allowed us to estimate the value of $\mathrm{IC}_{50}=2.5 \times 10^{-7} \mathrm{M}$ (Fig. 9C), which is in accordance with the value of APE1 association constants with F-containing DNA duplexes. ${ }^{38,39}$ Thus, the replacement of one of the non-bridging oxygen atoms in the phosphate group on the $5^{\prime}$-side from the F-site by the amino group to form a primary phosphoramidate did not significantly affect the affinity of APE1 for the DNA substrate. At the same time, the catalytic activity of APE1 has decreased considerably.

As a control, we have studied the kinetics of the interaction of APE1 with a DNA duplex $5^{\prime}$-d(CTCTCGCCTTCC)- $3^{\prime} / 3^{\prime}$ d(GAGAGCGGAAGG)-5' (G/C), which did not contain any of the modifications. As seen from Fig. 9B and C, duplex G/C slightly retards enzymatic activity of APE1 resulting in $\mathrm{IC}_{50}=$ $8.0 \times 10^{-6} \mathrm{M}$. Thus, inhibitory activity of the duplex $\mathrm{F}^{\mathrm{N}} / \mathrm{G}^{\mathrm{O}}$ is related to specific interactions of APE1 with the F-site.

It should be noted that $\mathrm{IC}_{50}$ for most of the reported smallmolecule inhibitors of APE1 is in the 1.0-10.0 $\times 10^{-6} \mathrm{M}$ range. ${ }^{43,44}$ One of the potent inhibitors of APE1 identified in the library of pharmacologically active compounds (LOPAC) was aurintricarboxylic acid (ATA), displaying an $\mathrm{IC}_{50}$ value of $5.5 \times 10^{-8} \mathrm{M}^{45}$ The developments in oligonucleotide synthesis provided an 

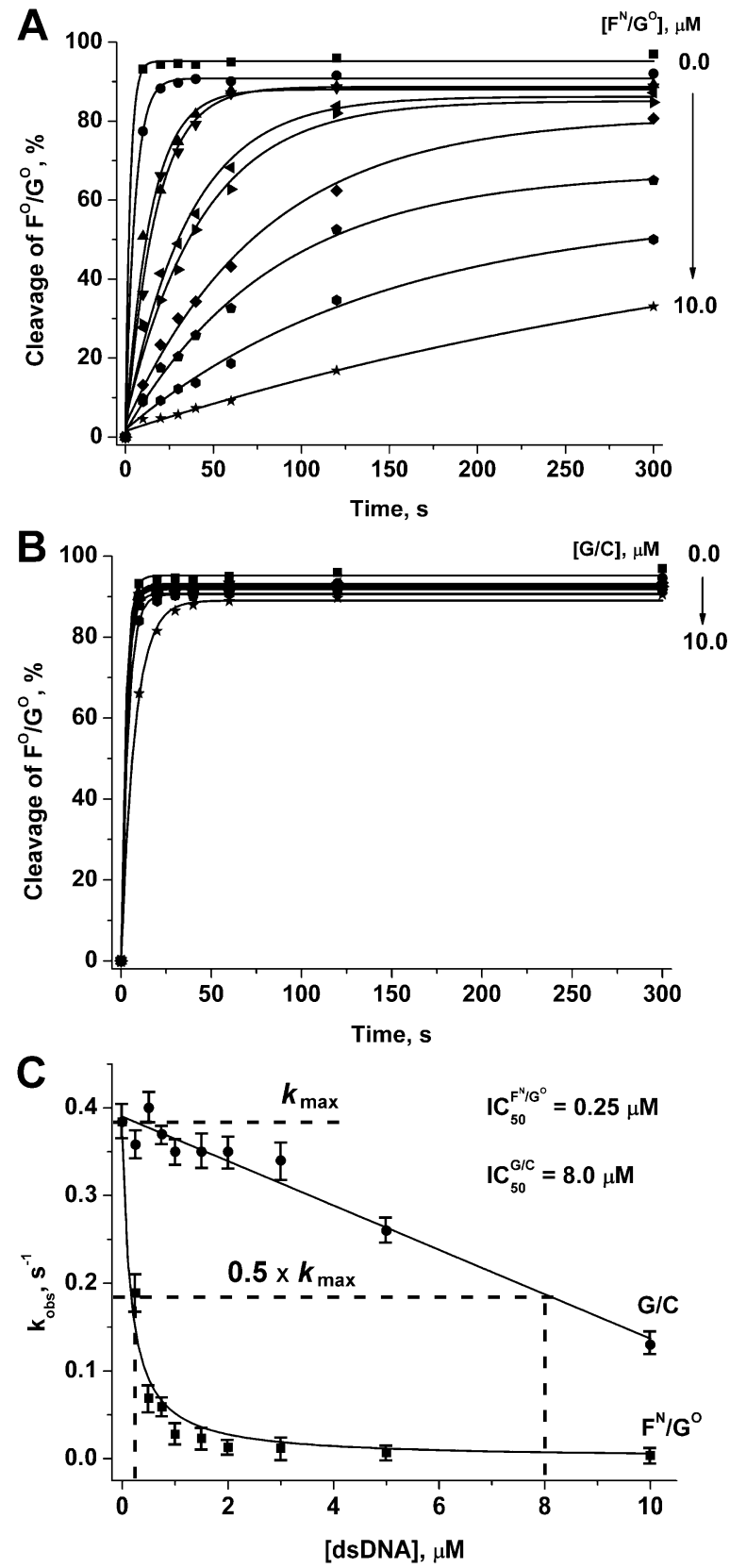

Fig. 9 APE1-catalysed hydrolysis of a duplex $\mathrm{F}^{\circ} / \mathrm{G}^{\circ}$ in the presence of duplexes $F^{N} / G^{\circ}(A)$ and $G / C(B)$. Estimation of the $I C_{50}$ value $(C)$. [APE1] = $\left[\mathrm{F}^{\mathrm{O}} / \mathrm{G}^{\circ}\right]=1.0 \mu \mathrm{M}$.

opportunity for their use as therapeutic agents. ${ }^{46,47}$ Therefore, the compounds reported in the present work could be used not only for biochemical and structural studies of AP endonucleases but also could have potential for subsequent application for therapy.

\section{Experimental}

The following chemicals were used in this work: $N, N, N^{\prime}, N^{\prime}$-tetraisopropyl-2-cyanoethylphosphordiamidite, $N, N$-diisopropylethylamine (DIEA), $1 H$-tetrazole, levulinic acid and acetylacetone were from Aldrich (USA), 1-methylimidazole, $N, N^{\prime}$-dicyclohexylcarbodiimide (DCC) and hydrazine hydrate were from Merck (FRG), the remainder were from "Reakhim" (Russia). All the reagents and solvents were used as purchased unless stated otherwise. Thin layer chromatography (TLC) was carried out on Kieselgel $60 \mathrm{~F}_{254}$ plates (Merck, FRG). The spots were visualized under UV light $(254 \mathrm{~nm})$ or by spraying with $0.25 \%$ cysteine solution in $30 \% \mathrm{H}_{2} \mathrm{SO}_{4}$ and heating. Flash column chromatography was on Kieselgel 55-100 $\mu \mathrm{m}$ (Merck, FRG). NMR spectra were recorded on a Brücker AM-400 spectrometer (FRG). Chemical shifts $\delta$ are reported in ppm against tetramethylsilane as an internal standard for ${ }^{1} \mathrm{H}$ and ${ }^{13} \mathrm{C}$ NMR spectra, and $85 \% \mathrm{H}_{3} \mathrm{PO}_{4}$ as an external standard for ${ }^{31} \mathrm{P}$ NMR spectra. ${ }^{13} \mathrm{C}$ and ${ }^{31} \mathrm{P}$ NMR spectra were recorded with proton decoupling unless stated otherwise. Mass spectra were recorded on an Agilent ESI MSD XCT Ion Trap mass spectrometer (USA) in the SB RAS "Proteomics" Core Facility.

1,4-Anhydro-2-deoxy-5-O-(4,4'-dimethoxytrityl)-D-ribitol (II) was prepared as described in ref. 41.

$3^{\prime}$-Amino- $N^{4}$-benzoyl-2' - $^{\prime}$-dideoxy-5'-O-(4,4'-dimethoxytrityl)cytidine (V) was obtained according to ref. 40

\section{1,4-Anhydro-2-deoxy-3-O-levulinyl-d-ribitol (III)}

To a solution of levulinic acid $(2.3 \mathrm{~g}, 19.5 \mathrm{mmol})$ in diethyl ether $(50 \mathrm{ml})$ solid DCC $(2.1 \mathrm{~g}, 10 \mathrm{mmol})$ was added in portions with stirring. After the reaction mixture was stirred for $3 \mathrm{~h}$, the precipitate was filtered and washed by diethyl ether $(10 \mathrm{ml})$, and the combined ether solution was concentrated in vacuo, the rest dissolved in pyridine $(20 \mathrm{ml})$ and added to 1,4-anhydro-2deoxy-5-O-(4,4'-dimethoxytrityl)-D-ribitol (II) (2.6 g, $6.5 \mathrm{mmol})$ and 1-methylimidazole $(0.8 \mathrm{ml}, 10 \mathrm{mmol})$. After $1 \mathrm{~h}$, the reaction was quenched by $5 \% \mathrm{NaHCO}_{3}$, concentrated in vacuo and partitioned between water and dichloromethane. The organic layer was dried over anhydrous $\mathrm{Na}_{2} \mathrm{SO}_{4}$, the solvent removed in vacuo, and the oily residue re-evaporated with toluene to remove traces of pyridine and dissolved in $80 \%$ aq. acetic acid $(10 \mathrm{ml})$. The mixture was stirred for $3 \mathrm{~h}$, then water $(50 \mathrm{ml})$ was added, and the volatiles removed in vacuo (traces of water eliminated by co-evaporation with acetonitrile). The residue was separated by chromatography on a silica gel column eluted with a gradient of acetone in dichloromethane 0-30\%. Yield of 1,4-anhydro-2-deoxy-3-O-levulinyl-D-ribitol (III) $0.85 \mathrm{~g}(60 \%) . R_{\mathrm{f}} 0.40\left(\mathrm{CH}_{2} \mathrm{Cl}_{2}-\mathrm{EtOH} 19: 1\right) .{ }^{1} \mathrm{H}$ NMR $\left(\mathrm{CDCl}_{3}\right)$ : $5.11(1 \mathrm{H}, \mathrm{dt}, J=6.6,2.3 \mathrm{~Hz}, \mathrm{H} 3), 4.06(1 \mathrm{H}, \mathrm{dt}, J=8.3,2.3 \mathrm{~Hz}, \mathrm{H} 4)$, 3.95-3.87 (2H, m, H1), 3.75 (1H, dd, $J=11.7,4.0 \mathrm{~Hz}, \mathrm{H} 5)$, $3.68(1 \mathrm{H}, \mathrm{dd}, J=11.7,4.0 \mathrm{~Hz}, \mathrm{H} 5), 2.83-2.72(2 \mathrm{H}, \mathrm{m}$, $\left.\mathrm{C}(\mathrm{O}) \mathrm{CH}_{2} \mathrm{CH}_{2} \mathrm{C}(\mathrm{O}) \mathrm{CH}_{3}\right), 2.65-2.53\left(2 \mathrm{H}, \mathrm{m}, \mathrm{C}(\mathrm{O}) \mathrm{CH}_{2} \mathrm{CH}_{2} \mathrm{C}(\mathrm{O}) \mathrm{CH}_{3}\right)$, $2.21\left(1 \mathrm{H}, \mathrm{s}, \mathrm{CH}_{3}\right), 2.19-2.13(1 \mathrm{H}, \mathrm{m}, \mathrm{H} 2), 2.06-2.00(1 \mathrm{H}, \mathrm{m}, \mathrm{H} 2) ;{ }^{13} \mathrm{C}$ NMR $\left(\mathrm{CDCl}_{3}\right): 206.5$, 172.7, 84.6, 76.3, 67.4, 62.7, 37.7, 32.9, 29.7, 27.9.

\section{1,4-Anhydro-2-deoxy-3-O-levulinyl-5-O-(2-cyanoethyl-H-phosphonyl)- D-ribitol (IV)}

To a solution of compound III $(0.68 \mathrm{~g}, 3.2 \mathrm{mmol})$ in dichloromethane $(15 \mathrm{ml})$ DIEA $(0.28 \mathrm{ml}, 1.6 \mathrm{mmol})$ followed by $1 H$-tetrazole $(0.1 \mathrm{~g}, 1.6 \mathrm{mmol})$ and $N, N, N^{\prime}, N^{\prime}$-tetraisopropyl-2cyanoethylphosphordiamidite $(1.0 \mathrm{ml}, 0.35 \mathrm{mmol})$ were added. 
After $1 \mathrm{~h}$ of stirring, $0.4 \mathrm{M}$ solution of $1 H$-tetrazole in $90 \%$ aq. MeCN (15 ml) was added, the mixture was stirred for another $1 \mathrm{~h}$ and partitioned between dichloromethane $(30 \mathrm{ml})$ and brine $(20 \mathrm{ml})$, the organic layer was washed by water $(20 \mathrm{ml})$, separated, dried over $\mathrm{Na}_{2} \mathrm{SO}_{4}$ and evaporated to foam. Yield of crude IV $0.95 \mathrm{~g}$ (94\%). $R_{\mathrm{f}} 0.13\left(\mathrm{CH}_{2} \mathrm{Cl}_{2}\right.$-AcOEt-EtOH $\left.17: 17: 2\right) .{ }^{1} \mathrm{H}$ NMR $\left(\mathrm{CDCl}_{3}\right): 6.93(0.5 \mathrm{H}, \mathrm{d}, J=725.0 \mathrm{~Hz}, \mathrm{PH}), 6.89(0.5 \mathrm{H}, \mathrm{d}, J=$ $725.0 \mathrm{~Hz}, \mathrm{PH}), 5.13-5.05$ (1H, m, H3), 4.35-3.79 (7H, m, H1, H4, $\left.\mathrm{H} 5, \mathrm{OCH}_{2} \mathrm{CH}_{2} \mathrm{CN}\right), 3.75-3.60(1 \mathrm{H}, \mathrm{m}, \mathrm{H} 5), 3.54-3.30(1 \mathrm{H}, \mathrm{m}$, $\mathrm{OC}_{2} \mathrm{CH}_{2} \mathrm{CN}$ ), 2.82-2.67 (2H, m, C(O) $\left.\mathrm{C}_{2} \mathrm{CH}_{2} \mathrm{C}(\mathrm{O}) \mathrm{CH}_{3}\right), 2.61-$ $2.49\left(2 \mathrm{H}, \mathrm{m}, \mathrm{C}(\mathrm{O}) \mathrm{CH}_{2} \mathrm{CH}_{2} \mathrm{C}(\mathrm{O}) \mathrm{CH}_{3}\right), 2.17\left(1 \mathrm{H}, \mathrm{s}, \mathrm{CH}_{3}\right), 2.14-2.06$ (1H, m, H2), 2.05-1.93 (1H, m, H2). ${ }^{31} \mathrm{P} \mathrm{NMR}\left(\mathrm{CDCl}_{3}\right): 8.97$ (c), 8.35 (c). ${ }^{31} \mathrm{P}$ NMR without $\mathrm{P}-\mathrm{H}$ decoupling $\left(\mathrm{CDCl}_{3}\right): 8.97$ (d quint, $J=725.0,9.8 \mathrm{~Hz}$ ), 8.35 (d quint, $J=725.0,9.8 \mathrm{~Hz}$ ).

$3^{\prime}-N$-[3'-Amino- $N^{4}$-benzoyl-2' $3^{\prime} 3^{\prime}$-dideoxy-5' $-O-\left(4,4^{\prime}\right.$-dimethoxytrityl)cytidyl]-(2-cyanoethyl)-phosphoryl-5-O-1,4-anhydro-2-deoxy-D-ribitol (VI)

$H$-Phosphonate IV $(0.95 \mathrm{~g}, 3.0 \mathrm{mmol})$ was dissolved in a $1: 1$ mixture of pyridine and $\mathrm{CCl}_{4}(18 \mathrm{ml})$, then TEA $(1.4 \mathrm{ml}$, $10 \mathrm{mmol})$ and aminonucleoside $\mathrm{V}(0.24 \mathrm{~g}, 0.38 \mathrm{mmol})$ were added with stirring. After $1 \mathrm{~h}$ of stirring, the solvent was removed in vacuo, the rest was dissolved in a 4:1 mixture of pyridine and acetic acid, and hydrazine hydrate $(0.5 \mathrm{ml}$, $10 \mathrm{mmol}$ ) was added. After $20 \mathrm{~min}$, the reaction was quenched by acetylacetone $(2.0 \mathrm{ml}, 20 \mathrm{mmol})$, diluted with dichloromethane $(50 \mathrm{ml})$ and washed by water $(2 \times 30 \mathrm{ml})$. The organic layer was dried by $\mathrm{Na}_{2} \mathrm{SO}_{4}$, dichloromethane was removed in vacuo, the residue was dissolved in dichloromethane and chromatographed on a silica gel column eluted by a gradient of ethanol in $\mathrm{CH}_{2} \mathrm{Cl}_{2}$ 0-20\%. Fractions containing VI were pooled, evaporated to a small volume, and the product precipitated by 10 fold volume of petroleum ether. Yield of VI $0.13 \mathrm{~g}(40 \%)$. $R_{\mathrm{f}} 0.35\left(\mathrm{CH}_{2} \mathrm{Cl}_{2}-\mathrm{EtOH} 9: 1\right) .{ }^{31} \mathrm{P} \mathrm{NMR}\left(\mathrm{CDCl}_{3}\right): 8.60,8.34(2 \mathrm{~s}$, mixture of diastereomers). ESI MS: calculated for $\mathrm{C}_{45} \mathrm{H}_{48} \mathrm{~N}_{5} \mathrm{O}_{11} \mathrm{P}$ 865.31, found $m / z 864.20[\mathrm{M}-\mathrm{H}]^{-}$.

\section{Dimer phosphoramidite (I)}

Phosphitylation was carried out as described in ref. 48. From $0.13 \mathrm{~g}$ of dimer VI $0.1 \mathrm{~g}$ of dimer phosphoramidite I were obtained (67\% yield). $R_{\mathrm{f}} 0.50\left(\mathrm{CH}_{2} \mathrm{Cl}_{2}-\mathrm{EtOH}, 9: 1\right) .{ }^{31} \mathrm{P}$ NMR $\left(\mathrm{CDCl}_{3}\right):$ 149.70, 149.66, 149.17, 149.02, 8.46, 7.88 (mixture of diastereomers).

\section{Oligonucleotide synthesis}

Automated synthesis of oligonucleotides was carried out on an ASM-800 DNA/RNA synthesiser ("Biosset", Russia) using dimer phosphoramidite I together with standard commercial 2-cyanoethyl deoxynucleoside phosphoramidites and CPG solid supports from Glen Research (USA). Dimer phosphoramidite I was used as a $0.1 \mathrm{M}$ solution in anhydrous acetonitrile. The volumes of $\mathbf{I}$ and activator $1 H$-tetrazole solutions were increased from 20 to $80 \mu \mathrm{l}$, and the reaction time was extended from 1 till $10 \mathrm{~min}$. Phosphorothioate groups were introduced using sulfurizing reagent II (3-((dimethylaminomethylidene)amino)-3H-1,2,4-dithiazole-3thione) from Glen Research, USA (0.1 M in pyridine-acetonitrile
$3: 2 \mathrm{v} / \mathrm{v}$ ) according to the manufacturer's protocol. Oligonucleotides with internucleotide tetramethyl phosphoryl guanidine group (1e) were obtained as described in ref. 42. Oligonucleotides with an internucleotide primary phosphoramidate group (1d) were prepared as described in ref. 49

Native and modified oligonucleotides were isolated by reverse-phased HPLC on an Agilent 1200 HPLC system (USA) using a Zorbax SB-C18 $5 \mu \mathrm{m}$ column $4.6 \times 150 \mathrm{~mm}$ in a linear gradient of acetonitrile $0-50 \%$ in $20 \mathrm{mM}$ triethylammonium acetate, pH 7.0 in $30 \mathrm{~min}$, a flow rate of $2 \mathrm{ml} \mathrm{min}^{-1}$. Fractions containing the desired product were pooled, concentrated in vacuo, dissolved in $0.1 \mathrm{ml}$ of deionised water and precipitated by $2 \% \mathrm{LiClO}_{4}$ in acetone. After centrifugation at $14500 \mathrm{rpm}$ for $2 \mathrm{~min}$, washing with acetone and drying on air for $20 \mathrm{~min}$, oligonucleotide pellets were dissolved in deionised water and stored at $-20{ }^{\circ} \mathrm{C}$. Oligonucleotide homogeneity was assessed by $20 \%$ denaturing PAGE in $8 \mathrm{M}$ urea, $0.1 \mathrm{M}$ Tris-borate buffer, $\mathrm{pH}$ 8.3. The bands were visualised by staining with Stains-All (Sigma, USA).

Molecular masses of oligonucleotides were checked by LC-MS/MS ESI MS on an Agilent G6410A mass spectrometer (USA) in a negative ion mode. The samples were prepared by dissolving oligonucleotides in $20 \mathrm{mM}$ triethylammonium acetate in $60 \%$ aq. acetonitrile until $0.1 \mathrm{mM}$ concentration. The volume of the sample was $10 \mu \mathrm{l}$. Analysis was carried out using $80 \%$ aq.

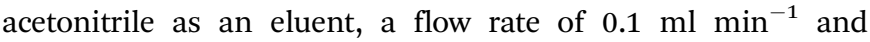
standard device settings. Molecular masses were calculated using experimental $\mathrm{m} / \mathrm{z}$ values, obtained for each sample. The results are given in Table 3 and Fig. 8.

\section{Enzymes and DNA duplexes}

DNA duplexes that were used as substrates are given in Fig. 2. Oligonucleotides were purified by ion exchange HPLC on a Hamilton PRP-X500 12-30 $\mu \mathrm{m} 3.9 \times 300 \mathrm{~mm}$ column followed by reverse-phased HPLC on a Nucleoprep 100-20 C18 $10 \times 250 \mathrm{~mm}$ column (Macherey-Nagel, FRG). Oligonucleotide homogeneity was checked by $20 \%$ denaturing PAGE.

APE1 enzyme was isolated from the $E$. coli Rosetta2 cell line transformed by a plasmid pET11a carrying human APE1 gene. ${ }^{50}$

Table 3 Molecular masses of oligonucleotides

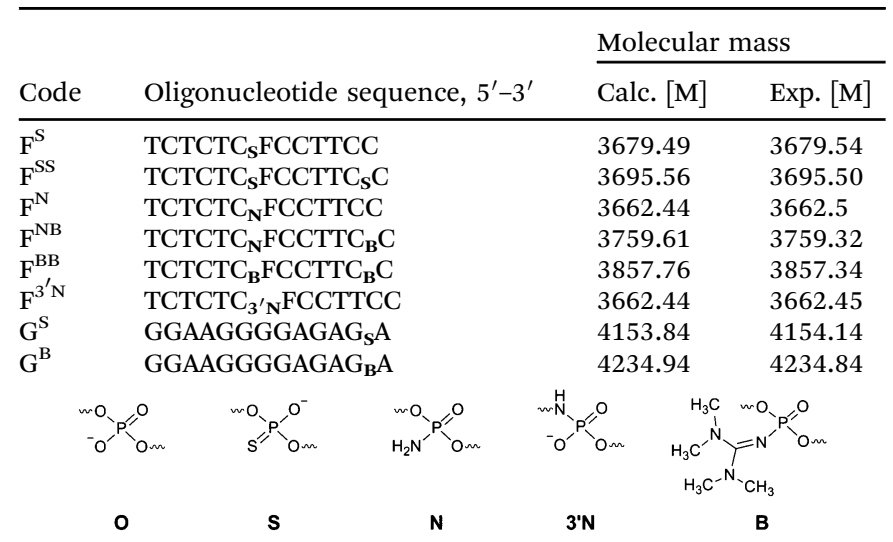




\section{PAGE time-course experiments}

$5^{\prime}-\left[{ }^{32} \mathrm{P}\right]$-Labelled oligonucleotides were used in experiments on separation of cleavage products by PAGE. The modified strands were ${ }^{32} \mathrm{P}$-labeled using $\left[\gamma_{-}{ }^{32} \mathrm{P}\right] \mathrm{ATP}$ and bacteriophage T4 polynucleotide kinase (New England Biolabs, Beverly, MA) according to the manufacturer's protocol.

Single-turnover APE1 endonuclease assays were performed in the reaction buffer of $50 \mathrm{mM}$ Tris- $\mathrm{HCl}, \mathrm{pH} 7.5,50 \mathrm{mM}$ $\mathrm{KCl}$, $0.1 \mathrm{mM}$ EDTA, $5 \mathrm{mM} \mathrm{MgCl}_{2}, 1 \mathrm{mM}$ DTT, 9\% glycerol at $25{ }^{\circ} \mathrm{C}$.

To register the cleavage extent of modified oligonucleotide duplexes the reaction solution contained 1.0 $\mu \mathrm{M}$ APE1 and 1.0 $\mu \mathrm{M}$ dsDNA. Cleavage of the modified oligonucleotide duplexes was initiated by the addition of APE1. Aliquots of $2 \mu \mathrm{l}$ of the reaction mixture were withdrawn at time intervals of $1,5,10,20,30,60,120$ and $180 \mathrm{~min}$, immediately quenched with $3 \mu$ l of gel-loading dye containing $7 \mathrm{M}$ urea and $50 \mathrm{mM}$ EDTA, and loaded on a $20 \%(\mathrm{w} / \mathrm{v})$ polyacrylamide/7 M urea gel.

To register the cleavage extent of the $\mathrm{F}^{\mathrm{O}} / \mathrm{G}^{\mathrm{O}}$ substrate in the presence of inhibitors the reaction solution contained $1.0 \mu \mathrm{M}$ APE1 and $1.0 \mu \mathrm{M} \mathrm{F}^{\mathrm{O}} / \mathrm{G}^{\mathrm{O}}$ and $0.0,0.25,0.5,0.75,1.0,1.5,2.0$, 3.0, 5.0 or $10.0 \mu \mathrm{M} \mathrm{F} / \mathrm{G}^{\mathrm{O}}$ and $\mathrm{G} / \mathrm{C}$ duplexes. The $\mathrm{F}^{\mathrm{O}} / \mathrm{G}^{\mathrm{O}}$ substrate was initially incubated with $\mathrm{F}^{\mathrm{N}} / \mathrm{G}^{\mathrm{O}}$ or $\mathrm{G} / \mathrm{C}$ for 5 min. Cleavage of the $\mathrm{F}^{\mathrm{O}} / \mathrm{G}^{\mathrm{O}}$ substrate was initiated by the addition of APE1. $2 \mu$ l aliquots of the reaction mixture were withdrawn at time intervals of 10, 20, 30, 40, 60, 120 and $300 \mathrm{~s}$, immediately quenched with $3 \mu$ l of gel-loading dye containing $7 \mathrm{M}$ urea and $50 \mathrm{mM}$ EDTA, and loaded on a $20 \%(\mathrm{w} / \mathrm{v})$ polyacrylamide/7 $\mathrm{M}$ urea gel.

The extent of cleavage was determined by radioautography and digital processing by Gel-pro Analyzer 4.0 software (Media Cybernetics, USA). The degree of cleavage was calculated as a ratio of the area of product peaks to the sum of the areas of the product and starting material peaks. All experiments were repeated in triplicate. The presented data points reflect the average value obtained from a set of repeats.

The fraction product was fitted by the single exponential curve using Origin software (Originlab Corp.) (eqn (1)).

$$
\text { [product }]=A \times\left[1-\exp \left(-k_{\text {obs }} \times t\right)\right]
$$

where $A$ is the amplitude, $k_{\text {obs }}$ is the observed rate constant, and $t$ is the reaction time (s).

\section{Stopped-flow fluorescence measurements}

Fluorescent kinetic curves were recorded on a stopped-flow spectrometer SX.18MV (Applied Photophysics, UK). For Trp fluorescence, excitation wavelength was $290 \mathrm{~nm}$. The change in Trp fluorescence emission was observed on wavelengths above $320 \mathrm{~nm}$ (Schott filter WG 320). The dead time of the device was $1.38 \mathrm{~ms}$, maximum recording time was $10 \mathrm{~s}$. Each kinetic curve was the result of averaging of minimum three experimental curves. All the experiments were carried out in $50 \mathrm{mM}$ Tris- $\mathrm{HCl}, \mathrm{pH}$ 7.5, $50 \mathrm{mM} \mathrm{KCl,} 0.1 \mathrm{mM}$ EDTA, $5 \mathrm{mM}$ $\mathrm{MgCl}_{2}, 1 \mathrm{mM}$ DTT, 9\% glycerol at $25{ }^{\circ} \mathrm{C}$.

\section{Fluorescence titration of APE1 with oligodeoxyribonucleotide} inhibitors

Dissociation constant $K_{\mathrm{d}}$ of the complex of APE1 with the inhibitors was determined by fluorescence titration. Each point on the fluorescence titration curves was obtained by the measurement of the fluorescence intensity of the reaction mixture $(100 \mu \mathrm{l})$ containing APE1 $\left(1.0 \times 10^{-6} \mathrm{M}\right)$ and an oligonucleotide inhibitor at the required concentration in a buffer (50 mM Tris-HCl, pH 7.5, $50 \mathrm{mM} \mathrm{KCl,} 0.1 \mathrm{mM}$ EDTA, $5 \mathrm{mM} \mathrm{MgCl}_{2}, 1 \mathrm{mM}$ DTT, 9\% glycerol). The mixtures were incubated at $25{ }^{\circ} \mathrm{C}$ for $2 \mathrm{~min}$. Fluorescence spectra were measured at an excitation wavelength of $290 \mathrm{~nm}$ using a Varian Cary Eclipse spectrofluorimeter (Agilent Technologies, USA). Values of fluorescence intensity at the emission maximum (335 nm) were used to calculate the dissociation constants.

The values of $K_{\mathrm{d}}$ were determined by non-linear regression analysis of data according to eqn (2), using program Origin software (Originlab Corp.).

$$
\begin{aligned}
F= & F_{\text {complex }} \times[\mathrm{APE} 1]_{0}+\left(F_{0}-F_{\text {complex }}\right) \\
& \times\left\{\frac{[\mathrm{APE} 1]_{0}-[\mathrm{dsDNA}]-K_{\mathrm{d}}}{2}\right. \\
& \left.+\sqrt{\left(\frac{[\mathrm{APE} 1]_{0}-[\mathrm{dsDNA}]-K_{\mathrm{d}}}{2}\right)^{2}+K_{\mathrm{d}} \times[\mathrm{APE} 1]_{0}}\right\}
\end{aligned}
$$

where, $F_{0}, F$ and $F_{\text {complex }}$ are fluorescence intensities of APE1 without added inhibitor, at any given concentration of the inhibitor, and at the saturating concentration of the inhibitor, respectively. $[\mathrm{APE} 1]_{0}$ and $[\mathrm{dsDNA}]_{0}$ are the total concentrations of APE1 and the inhibitor.

\section{Conclusions}

This work has focussed on the design, synthesis and analysis of oligodeoxyribonucleotide derivatives as unreactive substrate analogues of a key enzyme of the DNA repair, AP-endonuclease APE1. It was found that either S- or N-substitution of the oxygen atoms in the phosphate group on the $5^{\prime}$-side of the tetrahydrofuran analogue of the AP-site (F-site) leads to a significant decrease in the APE1 activity. The kinetic analysis demonstrated that these modified oligonucleotide duplexes could be used in vitro as specific uncleavable DNA substrate analogues of APE1 for biochemical or structural studies of AP-endonuclease mechanisms. Besides, the compounds in our opinion show promise for future cell and animal studies.

\section{Abbreviations}

$\begin{array}{ll}\text { APE1 } & \text { Human AP-endonuclease } 1 \\ \mathrm{Bz} & \text { Benzoyl } \\ \mathrm{CE} & \text { 2-Cyanoethyl } \\ \text { DCC } & N, N^{\prime} \text {-Dicyclohexylcarbodiimide } \\ \text { DIPEA } & N, N \text {-Diisopropylethylamine }\end{array}$


DMTr 4, 4' -Dimethoxytrityl

DTT Dithiothreitol

Lev Levulinyl

MeIm 1-Methylimidazole

Py Pyridine

TEA Triethylamine

Tet $1 H$-Tetrazole

Tmg 1,1,3,3-Tetramethylguanidine

AP-site Apurinic/apyrimidinic site

F $\quad(2 R, 3 S)$-2-(Hydroxymethyl)-3-hydroxytetrahydrofuran

\section{Acknowledgements}

The work was supported by the Presidential Grant for Leading Scientific Schools NS-1205.2014.4; Russian Foundation for Basic Research Grants No. 13-04-00013 to O. S. F., No. 14-0401018 to T. V. A., No. 15-34-20121 to A. A. K., No. 15-04-00467 to N. A. K., No. 13-04-01176 to D. V. P., No. 15-04-06331 and 15-2901334 to D. A. S.; bursary of the President of the Russian Federation (SP-3752.2015.4) to M. S. K. Part of the work with Trp fluorescence detection combined with stopped-flow kinetics was specifically funded by Russian Science Foundation grant No. 14-14-00063 to N. A. K. Synthesis of modified oligonucleotides was partly supported by the Ministry of Education and Science of the Russian Federation (Agreement No. 14.B25.31.0028).

\section{Notes and references}

1 T. Lindahl and B. Nyberg, Biochemistry, 1972, 11, 3610-3618.

2 J. H. Hoeijmakers, N. Engl. J. Med., 2009, 361, 1475-1485.

3 T. Iyama and D. M. Wilson, 3rd, DNA Repair, 2013, 12, 620-636.

4 S. Wolters and B. Schumacher, Front. Genet., 2013, 4, 19.

5 L. A. Loeb and C. C. Harris, Cancer Res., 2008, 68, 6863-6872.

6 L. H. Hurley, Nat. Rev. Cancer, 2002, 2, 188-200.

7 D. O. Zharkov, Cell. Mol. Life Sci., 2008, 65, 1544-1565.

8 A. B. Robertson, A. Klungland, T. Rognes and I. Leiros, Cell. Mol. Life Sci., 2009, 66, 981-993.

9 D. M. Wilson, 3rd and L. H. Thompson, Proc. Natl. Acad. Sci. U. S. A., 1997, 94, 12754-12757.

10 R. P. Cunningham, Mutat. Res., 1997, 383, 189-196.

11 S. C. Brooks, S. Adhikary, E. H. Rubinson and B. F. Eichman, Biochim. Biophys. Acta, 2013, 1834, 247-271.

12 B. Pascucci, G. Maga, U. Hubscher, M. Bjoras, E. Seeberg, I. D. Hickson, G. Villani, C. Giordano, L. Cellai and E. Dogliotti, Nucleic Acids Res., 2002, 30, 2124-2130.

13 J. L. Parsons and G. L. Dianov, DNA Repair, 2013, 12, 326-333.

14 E. Trushina and C. T. McMurray, Neuroscience, 2007, 145, 1233-1248.

15 M. S. Cooke, M. D. Evans, M. Dizdaroglu and J. Lunec, FASEB J., 2003, 17, 1195-1214.
16 M. D. Evans, M. Dizdaroglu and M. S. Cooke, Mutat. Res., 2004, 567, 1-61.

17 M. W. Germann, C. N. Johnson and A. M. Spring, Med. Res. Rev., 2012, 32, 659-683.

18 B. J. Glassner, G. Weeda, J. M. Allan, J. L. Broekhof, N. H. Carls, I. Donker, B. P. Engelward, R. J. Hampson, R. Hersmus, M. J. Hickman, R. B. Roth, H. B. Warren, M. M. Wu, J. H. Hoeijmakers and L. D. Samson, Mutagenesis, 1999, 14, 339-347.

19 A. Klungland, I. Rosewell, S. Hollenbach, E. Larsen, G. Daly, B. Epe, E. Seeberg, T. Lindahl and D. E. Barnes, Proc. Natl. Acad. Sci. U. S. A., 1999, 96, 13300-13305.

20 J. L. Parsons and R. H. Elder, Mutat. Res., 2003, 531, 165-175.

21 H. Nilsen, I. Rosewell, P. Robins, C. F. Skjelbred, S. Andersen, G. Slupphaug, G. Daly, H. E. Krokan, T. Lindahl and D. E. Barnes, Mol. Cell, 2000, 5, 1059-1065.

22 H. Fung and B. Demple, Mol. Cell, 2005, 17, 463-470.

23 R. L. Maher and L. B. Bloom, J. Biol. Chem., 2007, 282, 30577-30585.

24 K. M. Schermerhorn and S. Delaney, Biochemistry, 2013, 52, 7669-7677.

25 D. M. Wilson, 3rd, M. Takeshita, A. P. Grollman and B. Demple, J. Biol. Chem., 1995, 270, 16002-16007.

26 L. Y. Kanazhevskaya, V. V. Koval, Y. N. Vorobjev and O. S. Fedorova, Biochemistry, 2012, 51, 1306-1321.

27 M. A. Gorman, S. Morera, D. G. Rothwell, E. de La Fortelle, C. D. Mol, J. A. Tainer, I. D. Hickson and P. S. Freemont, EMBO J., 1997, 16, 6548-6558.

28 P. T. Beernink, B. W. Segelke, M. Z. Hadi, J. P. Erzberger, D. M. Wilson, 3rd and B. Rupp, J. Mol. Biol., 2001, 307, 1023-1034.

29 B. A. Manvilla, E. Pozharski, E. A. Toth and A. C. Drohat, Acta Crystallogr., Sect. D: Biol. Crystallogr., 2013, 69, 2555-2562.

30 C. D. Mol, T. Izumi, S. Mitra and J. A. Tainer, Nature, 2000, 403, 451-456.

31 C. D. Mol, D. J. Hosfield and J. A. Tainer, Mutat. Res., 2000, 460, 211-229.

32 S. E. Tsutakawa, D. S. Shin, C. D. Mol, T. Izumi, A. S. Arvai, A. K. Mantha, B. Szczesny, I. N. Ivanov, D. J. Hosfield, B. Maiti, M. E. Pique, K. A. Frankel, K. Hitomi, R. P. Cunningham, S. Mitra and J. A. Tainer, J. Biol. Chem., 2013, 288, 8445-8455.

33 A. S. Lipton, R. W. Heck, S. Primak, D. R. McNeill, D. M. Wilson, 3rd and P. D. Ellis, J. Am. Chem. Soc., 2008, 130, 9332-9341.

34 N. Oezguen, C. H. Schein, S. R. Peddi, T. D. Power, T. Izumi and W. Braun, Proteins, 2007, 68, 313-323.

35 E. Wickstrom, Adv. Drug Delivery Rev., 2015, 87, 25-34.

36 D. M. Wilson III and D. Barsky, Mutat. Res., 2001, 485, 283-307.

37 S. S. David and S. D. Williams, Chem. Rev., 1998, 98, 1221-1261.

38 N. A. Timofeyeva, V. V. Koval, D. G. Knorre, D. O. Zharkov, M. K. Saparbaev, A. A. Ishchenko and O. S. Fedorova, J. Biomol. Struct. Dyn., 2009, 26, 637-652. 
39 L. Y. Kanazhevskaya, V. V. Koval, D. O. Zharkov, P. R. Strauss and O. S. Fedorova, Biochemistry, 2010, 49, 6451-6461.

40 S. M. Gryaznov and R. L. Letsinger, Nucleic Acids Res., 1992, 20, 3403-3409.

41 R. Eritja, P. A. Walker, S. K. Randall, M. F. Goodman and B. E. Kaplan, Nucleosides Nucleotides, 1987, 6, 803-814.

42 M. S. Kupryushkin, D. V. Pyshnyi and D. A. Stetsenko, Acta naturae, 2014, 6, 116-118.

43 D. M. Wilson, 3rd and A. Simeonov, Cell. Mol. Life Sci., 2010, 67, 3621-3631.

44 R. I. Al-Safi, S. Odde, Y. Shabaik and N. Neamati, Curr. Mol. Pharmacol., 2012, 5, 14-35.
45 A. Simeonov, A. Kulkarni, D. Dorjsuren, A. Jadhav, M. Shen, D. R. McNeill, C. P. Austin and D. M. Wilson, PLoS One, 2009, 4, e5740, DOI: 10.1371/journal.pone.0005740.

46 V. Wacheck and U. Zangemeister-Wittke, Critical reviews in oncology/hematology, 2006, 59, 65-73.

47 D. Castanotto and C. A. Stein, Curr. Opin. Oncol., 2014, 26, 584-589.

48 S. V. Vasil'eva, T. V. Abramova, T. M. Ivanova, G. V. Shishkin and V. N. Silnikov, Bioorg. Khim., 2004, 30, 264-272.

49 D. A. Stetsenko, M. S. Kupryushkin and D. V. Pyshnyi, Russian Pat., 2014117293, 2014.

50 S. Daviet, S. Couve-Privat, L. Gros, K. Shinozuka, H. Ide, M. Saparbaev and A. A. Ishchenko, DNA Repair, 2007, 6, 8-18. 